\title{
Pengaruh Penambahan Aluminium Pasta dengan Sikacim Concrete Additive atau Katalis Mekpo Terhadap Sifat Fisis Papan Beton Ringan Berserat Sabut Kelapa
}

\author{
Deri Wahyuni*, Alimin Mahyudin \\ Laboratorium Fisika Material, Jurusan Fisika \\ Fakultas Matematika dan Ilmu Pengetahuan Alam Universitas Andalas \\ Kampus Unand Limau Manis, Padang 25163 Indonesia \\ *deriwahyuni66@gmail.com
}

\begin{abstract}
ABSTRAK
Telah dilakukan penelitian tentang pengaruh penambahan aluminium pasta dengan sikacim concrete additive dan katalis MEKPO terhadap sifat fisis papan beton ringan berserat sabut kelapa. Penelitian bertujuan untuk mengetahui persentase optimum penambahan aluminium pasta terhadap sifat fisik dan sifat mekanik pada papan beton ringan berserat sabut kelapa. Persentase aluminium pasta yang digunakan adalah $0,05 \%, 0,1 \%, 0,2 \%, 0,3 \%$, dan $0,4 \%$. Pengujian yang dilakukan pada sampel yaitu uji sifat fisik (densitas dan porositas) dan uji sifat mekanik (kuat tekan dan kuat lentur). Penambahan aluminium pasta dengan sikacim concrete additive dan katalis MEKPO menurunkan densitas karena bertambahnya porositas. Densitas minimum sebesar1,71 g/cm3 didapatkan pada penambahan aluminium pasta $0,4 \%$ dengan sikacim concrete additive. Porositas maksimum sebesar 39,1\% didapat pada penambahan aluminium pasta $0,4 \%$ dengan sikacim concrete additive. Nilai kuat tekan maksimum sebesar $78 \mathrm{~kg} / \mathrm{cm} 2$ pada penambahan aluminium pasta $0,05 \%$ dengan sikacim concrete additive dan kuat tekan semakin berkurang ketika penambahan aluminium pasta semakin meningkat. Kuat lentur maksimum yang dihasilkan sebesar $72 \mathrm{~kg} / \mathrm{cm} 2$ pada penambahan aluminium pasta $0,1 \%$ dengan sikacim concrete additive. Semakin besar penambahan aluminium pasta, semakin menurun kuat lentur. Sifat fisik dan sifat mekanik papan beton ringan dengan sikacim concrete additive lebih baik dari papan beton ringan dengan katalis MEKPO. Densitas, porositas dan kuat tekan papan beton ringan berserat sabut kelapa telah memenuhi standar SNI- 03-3449-2002 dan SNI-03-2105-2006 namun kuat lentur belum memenuhi standar.

Kata kunci: aluminium pasta, sikacim concrete additive, katalis MEKPO, serat sabut kelapa, papan beton ringan
\end{abstract}

\begin{abstract}
Effect of addition of aluminium pasta with sikacim concrete additive and MEKPO catalyst on physical and mechanical properties of lightweight concrete board coconut fiber has been investigated. The study is aimed at determining the optimum percentage of aluminium pasta to obtain bestphysical and mechanical properties of lightweight concrete board. The percentage of aluminiumpasta was $0.05 \%$, $0.1 \%, 0.2 \%, 0.3 \%$, and $0.4 \%$. The sampleswere tested their physical properties (density and porosity) and mechanical properties (compressive strength and flexural strength). The concentration of aluminium pasta andsikacim concrete additive and MEKPO catalyst is inversely proportional to porosity. The minimumdensity of $1.71 \mathrm{~g} / \mathrm{cm}^{3}$ is obtained for sample with addition of $0.4 \%$ aluminium pasta with sikacim concrete additive. The maximum of porosity of $39.1 \%$ is obtained for sample with addition of $0.4 \%$ aluminium pasta with sikacim concrete additive. The maximum value of compressive strength of 78 $\mathrm{kg} / \mathrm{cm}^{2}$ with the addition of aluminium pasta for $0.05 \%$ with sikacim concrete additive. The compressive strength decreases with the increases of aluminium pasta additive. The maximumflexural strength of 72 $\mathrm{kg} / \mathrm{cm}^{2}$ is obtained for sample with the addition of $0.1 \%$ aluminium pasta with sikacim concrete additive. The greater the addition of aluminium pasta, the lower the flexural strength.Physical and mechanical properties of lightweight concrete board with sikacim concrete additive is better than lightweight concrete board with MEKPO catalyst. Density, porosity, and compressive strength of coconut fibrous fiber lightweight concrete's boards meets the standards of SNI 03-3449-2002 and SNI 03-2105-2006, except their flexural strength.

Keyword: aluminium pasta, sikacim concrete additive, MEKPO catalyst, coconut coir fiber, lightweight concrete board
\end{abstract}

\section{PENDAHULUAN}

Perkembangan bahan bangunan terutama beton, saat ini semakin pesat. Hal ini terjadi karena kebutuhan penduduk terhadap bahan bangunan meningkat dan pertumbuhan penduduk yang tinggi. Beton memiliki kelebihan yaitu kuat tekan yang relatif tinggi, mudah dibentuk 
sesuai kebutuhan, perawatan murah dan dapat dikombinasikan dengan bahan lain (Zulkifly dkk, 2013).

Glassfiber Reinforced Cement (GRC) salah satu produk bahan material yang banyak diminati oleh masyarakat selain beton. GRC menurut British Standard Institution adalah material yang terbuat dari campuran pasta semen-pasir yang diperkuat dengan serat kaca. GRC memiliki kelemahan seperti densitas cukup tinggi yang menyebabkan waktu yang cukup lama untuk melakukan proses instalasinya. GRC yang beredar di pasaran memiliki densitas yang cukup tinggi yaitu 1,80-2,10 $\mathrm{g} / \mathrm{cm}^{3}$ (Fiber Technologies, 2013). Serat kaca pada GRC mempunyai harga mahal dan tidak dapat didaur ulang sehingga menimbulkan pencemaran lingkungan. Kelemahan yang dimiliki GRC dapat diatasi dengan membuat papan beton ringan dengan bahan tambahan murah dan ramah lingkungan yaitu serat sabut kelapa.

Papan beton ringan adalah papan beton yang mengandung agregat ringan dan mempunyai densitas tidak lebih dari $1,90 \mathrm{~g} / \mathrm{cm}^{3}$ (SNI-03-3449-2002). Papan beton ringan akan terbentuk dari penambahan aluminium pasta pada campuran pasta beton. Jatmika (2018) membuat papan beton ringan dengan penambahan aluminium pasta sebanyak 0,2\% menghasilkan densitas sebesar $1,502 \mathrm{~g} / \mathrm{cm}^{3}$. Penelitian Jatmika (2018) menghasilkan papan beton ringan sesuai dengan SNI 03-3449-2002 akan tetapi nilai kuat tekan dari papan beton ringan yang dihasilkan belum sesuai dengan syarat papan beton ringan struktural minimum SNI 03-3449-2002 yaitu sebesar $68,9 \mathrm{~kg} / \mathrm{cm}^{2}$. Papan beton ringan dengan campuran aluminium pasta dapat ditingkatkan kekuatannya dengan menambahkan bahan serat alam. Serat alam yang dapat digunakan sebagai bahan tambahan untuk papan beton ringan diantaranya serat jerami, serat sabut kelapa dan serat pinang.

Serat alam yang dipilih untuk penelitian ini yaitu serat sabut kelapa.Serat sabut kelapa adalah jenis serat yang memiliki kuat tarik sebesar $1784,5 \mathrm{~kg} / \mathrm{cm}^{2}$ dan memiliki nilai keuletan (ductility) paling tinggi dibandingkan serat yang lain yaitu 30\% (Bledzki dan Gassan, 1999). Serat sabut kelapa memiliki selulosa dan lignin yang lebih banyak dibandingkan dengan serat yang lain. Selulosa yang dimiliki serat sabut kelapa terdapat polimer yang saling terikat sehingga serat menjadi kuat dan meningkatkan kuat tarik dan kelenturan bahan. Lignin memiliki kandungan karbon yang berguna untuk tahan terhadap perubahan lingkungan dan kimia.

Sikacim concrete addittive dan katalis Methyl Ethyl Ketone Peroxide (MEKPO) merupakan zat aditif yang berguna untuk mempercepat pengerasan pada papan beton ringan. Penambahan zat aditif ini akan mempengaruhi waktu pengerjaan pada papan beton ringan. Dzikri (2018) melakukan penelitian dengan memvariasikan konsentrasi sikacim dan umur beton dan menghasilkan nilai kuat tekan semakin besar ketika konsentrasi sikacim dan umur beton bertambah. Nilai maksimum kuat tekan yang dihasilkan pada penambahan sikacim 1,5\% dengan waktu 56 hari pada papan beton lebih besar dari papan beton tanpa penambahan sikacim yaitu $30,55 \mathrm{~N} / \mathrm{mm}^{2}$ dengan $23,98 \mathrm{~N} / \mathrm{mm}^{2}$.

\section{METODE}

Pembuatan sampel dan pengujian sifat fisik dilakukan di Laboratorium Fisika Material Jurusan Fisika Unand sedangkan pengujian sifat mekanik dilakukan di Laboratorium Mekanik Politeknik Negeri Padang. Bahan yang digunakan dalam penelitian ini yaitu aluminium pasta yang berguna sebagai pengembang dan penghasil pori-pori sehingga papan beton menjadi ringan dengan variasi $0,05 \% ; 0,1 \% ; 0,2 \% ; 0,3 \%$ dan $0,4 \%$. Serat sabut kelapa digunakan sebagai penguat ikatan matriks yang panjangnya $\sim 1 \mathrm{~cm}$ dan volumenya $0,4 \%$. Semen, pasir, dan air digunakan sebagai bahan matriks serta sikacim concrete additive $2 \%$ dan katalis MEKPO 1\% digunakan sebagai mempercepat proses pengerasan pada papan beton. Papan beton ringan dibuat dengan ukuran $5 \mathrm{~cm} \times 5 \mathrm{~cm} \times 1 \mathrm{~cm}$ untuk pengujian densitas, porositas, dan kuat tekan serta ukuran $20 \mathrm{~cm}$ x $5 \mathrm{~cm}$ x $1 \mathrm{~cm}$ untuk pengujian kuat lentur.

Sabut kelapa diambil dari bagian dalam buah kelapa dan dibersihkan dari gabus yang masih menempel.Kemudian serat sabut kelapa dipotong dengan ukuran panjang $\sim 1 \mathrm{~cm}$. Sabut kelapa yang sudah bersih dan dipotong direndam dengan larutan $\mathrm{NaOH} 5 \%$ selama 2 jam. Setelah itu sabut kelapa dibilas dengan aquades untuk menghilangkan kandungan $\mathrm{NaOH}$ yang 
tersisa. Lalu serat dikeringkan pada suatu ruangan untuk menghilangkan kadar air yang tersisa. Serat sabut kelapa siap digunakan dalam proses pembuatan sampel uji.

Papan beton ringan dibuat dengan melakukan tahap-tahap berikut yaitu semen dan pasir dicampur dan diaduk hingga merata dengan ditambahkan air sedikit demi sedikit untuk membuat pasta beton. Volume semen, pasir, dan air yang digunakan secara berturut-turut adalah 28,99\%; 57,97\%; dan 11,59\% dari volume cetakan. Aluminium pasta dibuat dari campuran sebuk alumunium dengan air kemudian dimasukkan ke dalam pasta beton dan diaduk. Aluminium pasta dan pasta beton yang telah tercampur rata ditambah dengan sikacim concrete additive atau katalis MEKPO. Komposit pasta beton ringan yang telah selesai dibuat dimasukkan ke dalam cetakan hingga setengah cetakan. Serat sabut kelapa yang telah dikeringkan disusun di atas komposit pasta beton ringan lalu komposit pasta beton ringan dimasukkan kembali ke cetakan hingga terisi penuh. Cetakan yang terisi penuh diratakan dengan sendok semen dan didiamkan selama 7 hari, 14 hari, 21 hari, dan 28 hari dengan dikondisikan pada suhu ruang. Setelah itu komposit papan beton ringan siap dilakukan pengujian.

\subsection{Pengujian Densitas}

Densitasdidapat dengan mengukur massakering papan dalam satuan $\mathrm{g}$ dan mengukur panjang, lebar serta tebal papan untuk mendapatkan volumenya dalam satuan $\mathrm{cm}^{3}$. Nilai densitas didapat dengan menggunakan Persamaan (1)

$$
\rho=\frac{m}{V}
$$

dengan $\rho$ adalah densitas $\left(\mathrm{g} / \mathrm{cm}^{3}\right), m$ adalah massa sampel kondisi kering oven $(\mathrm{g})$, dan $V$ adalah volume sampel $\left(\mathrm{cm}^{3}\right)$.

\subsection{Pengujian Porositas}

Pengujian porositas dilakukan untuk mengetahui pori-pori atau rongga udara pada papan beton ringan. Mula-mula sampel uji direndam dalam wadah berisi air pada suhu 25 oC selama 24 jam. Lalu sampel uji dikeluarkan dari wadah dan dikeringkan dengan kain hingga airnya tidak menetes lagi. Kemudian sampel uji ditimbang menggunakan neraca digital dan dicatat hasilnya sebagai $m_{b}$. Nilai posositas sampel uji didapat dengan menggunakan Persamaan 2

$$
P(\%)=\frac{m_{b}-m}{V} \frac{1}{\rho_{a}} 100 \%
$$

dengan $P$ adalah porositas $(\%), m_{b}$ adalah massa basah sampel setelah direndam $(\mathrm{g}), m$ adalah massa sampel kondisi kering oven $(\mathrm{g}), V$ adalah volume sampel $\left(\mathrm{cm}^{3}\right)$, dan $\rho_{a}$ adalah massa jenis air yaitu $1 \mathrm{~g} / \mathrm{cm}^{3}$.

\subsection{Pengujian Kuat Tekan}

Sampel uji disiapkan dan diukur dimensi panjang, lebar dan tebalnya menggunakan jangka sorong dan dicatat hasil pengukurannya. Kemudian dilakukan pengujian kuat tekan dengan menggunakan mesin UTM dengan meletakkan sampel uji pada tumpuan. Sampel uji diberi beban secara vertikal dengan kecepatan sekitar $2 \mathrm{~mm} /$ menit. Kemudian dicatat perubahan sampel uji akibat diberi beban maksimum secara vertikal hingga sampel uji retak sebagai nilai P. Setelah itu dilakukan perhitungan nilai kuat tekan menggunakan Persamaan (3)

$$
f_{c}=\frac{P}{A}
$$

dengan $f_{c}$ adalah kuat tekan $\left(\mathrm{kg} / \mathrm{cm}^{2}\right), P$ adalah beban retak maksimum sampel $(\mathrm{kg})$, dan $A$ adalah luas permukaan sampel $\left(\mathrm{cm}^{2}\right)$. 


\subsection{Pengujian Kuat Tekan}

Sampel uji disiapkan dan diukur lebar dan tebalnya menggunakan jangka sorong. Pengujian kuat lentur dilakukan menggunakan mesin UTM dengan meletakkan sampel uji secara mendatar pada tumpuan. Lalu beban diberikan pada bagian pusat (ditengah) sampel uji dengan kecepatan sekitar $10 \mathrm{~mm} /$ menit. Kemudian dicatat perubahan sampel uji akibat diberi beban secara vertikal (tegak lurus) hingga sampel uji patah sebagai nilai mp. Setelah itu dilakukan perhitungan nilai kuat lentur menggunakan Persamaan (4)

$$
f_{r}=\frac{3 m_{p} S}{2 L T^{2}}
$$

dengan $f_{r}$ adalah kuat lentur $\left(\mathrm{kg} / \mathrm{cm}^{2}\right), m_{p}$ adalah beban patah maksimum $(\mathrm{kg}), S$ adalah jarak tumpuan (cm), $L$ adalah lebar sampel uji (cm), dan $T$ adalah tebal sampel uji $(\mathrm{cm})$.

\section{HASIL DAN DISKUSI}

\subsection{Densitas}

Gambar 1 memperlihatkan penurunan densitas dengan penambahan aluminium pasta mulai dari $0,05 \% ; 0,1 \% ; 0,2 \% ; 0,3 \% ; 0,4 \%$. Papan beton ringan dengan sikacim concrete additive memiliki densitas tertinggi pada persentase aluminium pasta $0,05 \%$ sebesar $2.02 \mathrm{~g} / \mathrm{cm}^{3}$. Persentase aluminium pasta $0,4 \%$ pada papan beton ringan dengan sikacim concrete additive menghasilkan densitas terendah sebesar $1,71 \mathrm{~g} / \mathrm{cm}^{3}$. Densitas tertinggi yang didapatkan pada penambahan aluminium pasta dengan tambahan katalis MEKPO $0,05 \%$ sebesar $2,02 \mathrm{~g} / \mathrm{cm}^{3}$ dan densitas terendah dihasilkan dari penambahan aluminium pasta $0,4 \%$ sebesar $1,76 \mathrm{~g} / \mathrm{cm}^{3}$. Penambahan aluminium pasta $0,05 \%$ menghasilkan densitas tertinggi karena aluminium pasta tidak terlalu bereaksi dengan campuran pasta beton sehingga kurangnya pembentukan pori-pori udara yang menyebabkan papan beton menjadi lebih ringan. Densitas rata-rata yang dihasilkan papan beton ringan dengan tambahan sikacim concrete additive yang telah memenuhi standar SNI 03-2105-2006 yaitu pada penambahan aluminium pasta $0,1 \%$ hingga $0,4 \%$ sedangkan katalis MEKPO pada penambahan aluminium pasta $0,3 \%$ dan $0,4 \%$.

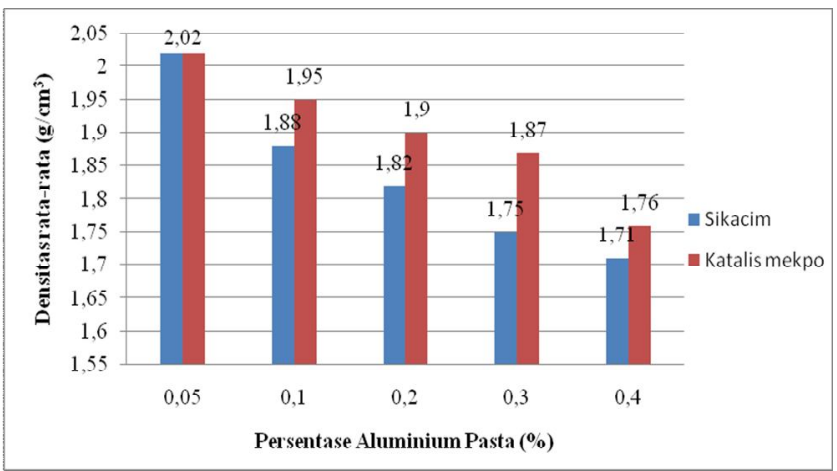

Gambar 1 Pengaruh penambahan aluminium pasta terhadap densitas papan beton ringan dengan sikacim concrete additive dan papan beton ringan dengan katalis MEKPO

\subsection{Porositas}

Gambar 2 menunjukkan nilai porositas semakin meningkat ketika persentase aluminium yang ditambahkan pada campuran pasta beton juga semakin meningkat. Hal ini terjadi karena aluminium pasta yang ditambahkan semakin banyak sehingga reaksi pembentukkan gas hidrogen juga semakin meningkat dan pori-pori yang yang terbentuk juga semakin banyak. 


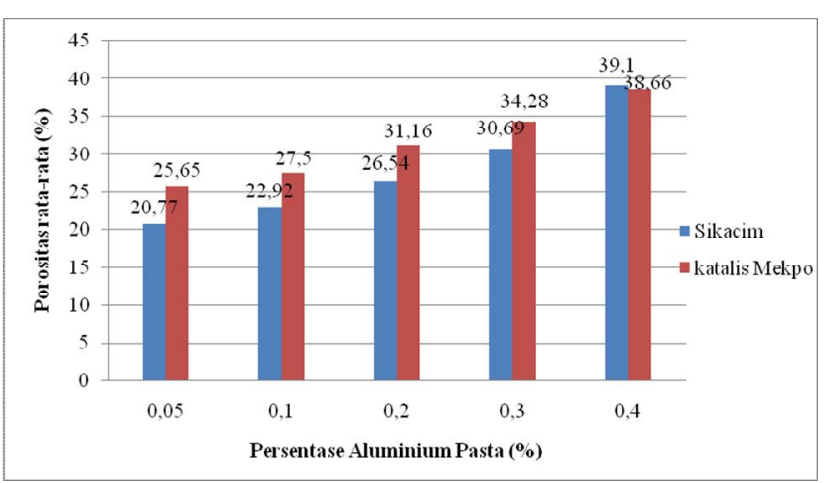

Gambar 2 Pengaruh penambahan aluminium pasta terhadap porositas papan beton ringan dengan sikacim concrete additive dan papan beton ringan dengan katalis MEKPO

Porositas terendah yang didapatkan pada penambahan aluminium pasta $0,05 \%$ dengan sikacim concrete additive sebesar $20,77 \%$ dan porositas tertinggi didapatkan pada penambahan aluminium pasta $0,4 \%$ yaitu $39,1 \%$. Papan beton ringan dengan tambahan katalis MEKPO menghasilkan porositas tertinggi pada aluminium pasta $0,4 \%$ sebesar $38,66 \%$ sedangkan porositas terendah dihasilkan pada penambahan aluminium pasta $0,05 \%$ sebesar $25,65 \%$. Papan beton ringan dengan tambahan sikacim concrete additive menghasilkan porositas rata-rata sesuai standar SNI 03-2105-2006 yaitu tidak lebih dari 25\% terjadi pada penambahan aluminium pasta $0,05 \%$ dan $0,1 \%$. Porositas rata-rata yang dihasilkan papan beton ringan dengan tambahan katalis MEKPO tidak ada yang memenuhi standar untuk setiap penambahan aluminium pasta.

\subsection{Kuat Tekan}

Gambar 3 dapat dilihat bahwa setiap persentase penambahan aluminium pasta pada campuran pasta beton dengan sikacim concrete additive maupun katalis MEKPO menghasilkan kenaikan nilai kuat tekan untuk variasi waktu 7 hari hingga 28 hari.

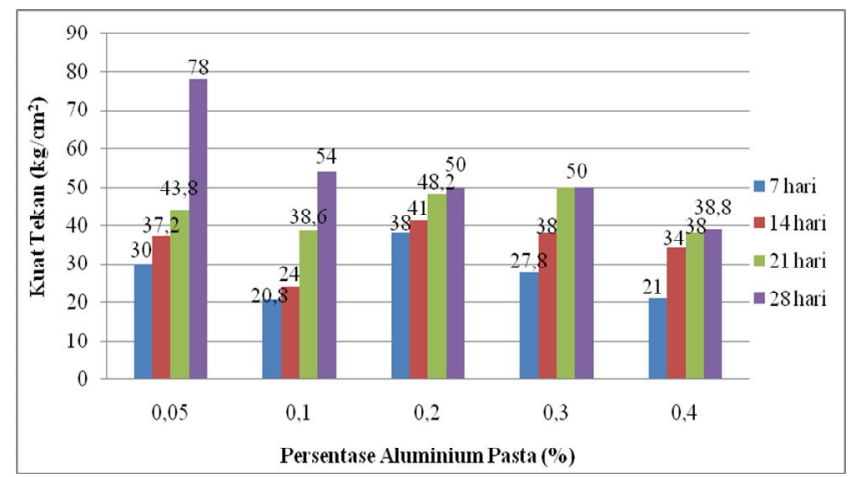

(a)

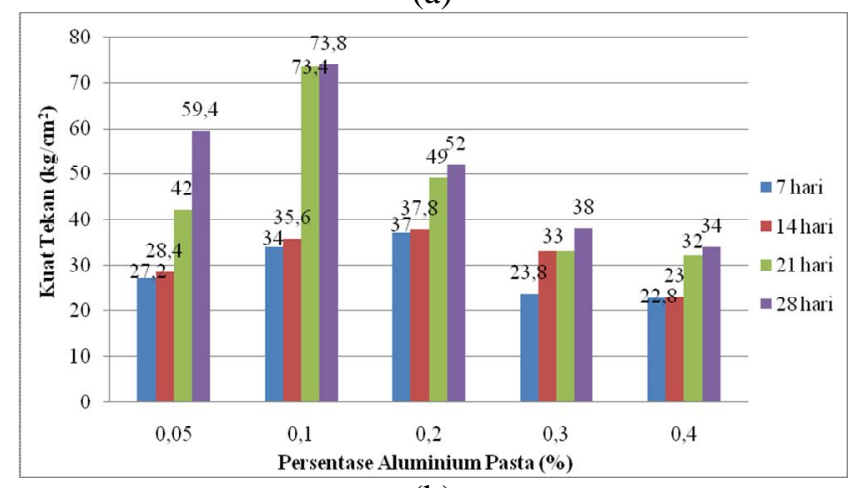

(b)

Gambar 3 Pengaruh penambahan aluminium pasta terhadap kuat tekan papan beton ringan berserat sabut kelapa dengan (a) sikacim concrete additive (b) katalis MEKPO 
Gambar 3 (a) dapat dilihat bahwa setiap umur beton akan mengalami penurunan kuat tekan ketika persentase penambahan aluminium pasta semakin meningkat.Hal ini diperkuat dengan hasil penelitian Putra (2015) dimana kuat tekan menurun ketika aluminium pasta bertambah dan nilai kuat tekan maksimum didapat pada penambahan aluminium pasta paling sedikit.Nilai kuat tekan yang turun disebabkan karena terbentuknya rongga udara pada papan beton ringan sehingga papan beton ringan tidak dapat menahan beban ketika diberi tekanan. Kuat tekan yang dihasilkan mengalami peningkatan pada penambahan aluminium pasta $0,1 \%$ dan mengalami penurunan hingga penambahan $0,4 \%$ seperti yang ditunjukkan pada Gambar 3 (b).

Kuat tekan maksimum yang didapat telah memenuhi standar SNI 03-3449-2002 yaitu pada penambahan aluminium pasta $0,05 \%$ dengan sikacim concrete additive sebesar $78 \mathrm{~kg} / \mathrm{cm} 2$ dan pada penambahan aluminium pasta $0,1 \%$ dengan katalis MEKPO sebesar 73,8 kg/cm2 . Kuat tekan yang telah dihasilkan ini termasuk pada tipe stuktural ringan.

\subsection{Kuat Lentur}

Kuat lentur beban yang dihasilkan meningkat dengan penambahan aluminium pasta ketika umur papan beton ringan bertambah. Penambahan aluminium pasta untuk setiap umur beton semakin meningkat menghasilkan kuat lentur semakin menurun. Kuat lentur maksimum dihasilkan pada penambahan aluminium pasta $0,1 \%$ umur 28 hari yaitu sebesar $72 \mathrm{~kg} / \mathrm{cm}^{2}$ dan kuat lentur minimum dihasilkan pada penambahan aluminium pasta $0,4 \%$ umur 7 hari sebesar $27 \mathrm{~kg} / \mathrm{cm}^{2}$ seperti yang terlihat pada Gambar 4 (a).

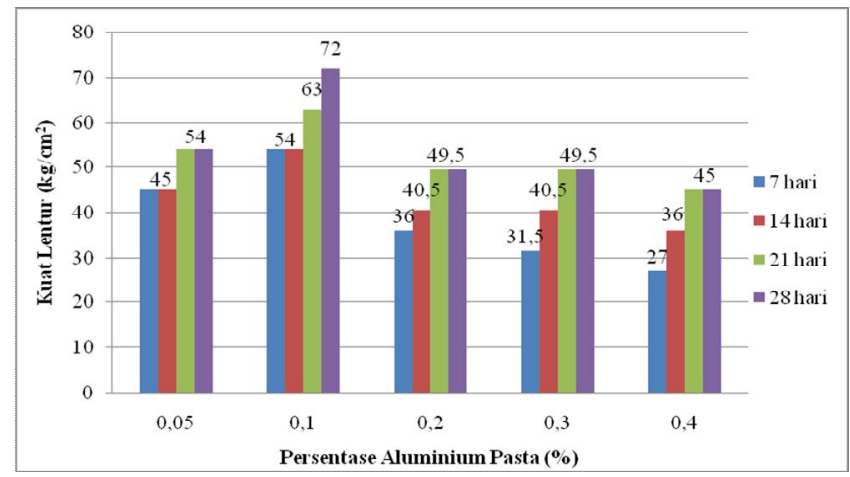

(a)

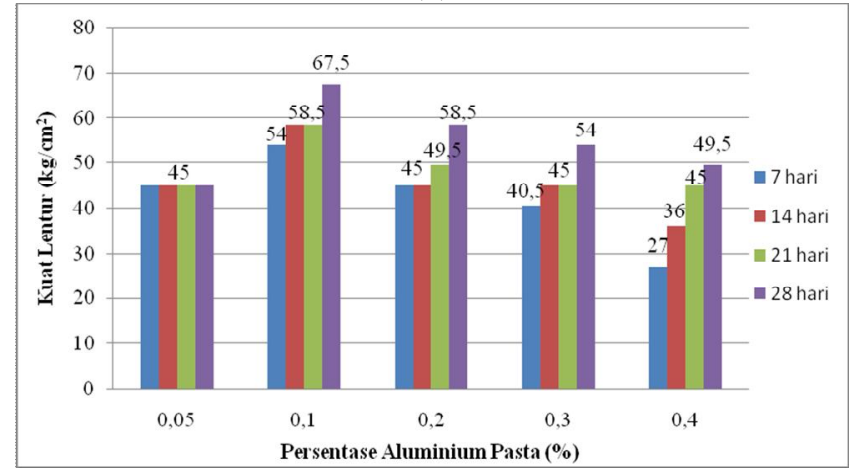

(b)

Gambar 4 Pengaruh penambahan aluminium pasta terhadap kuat lentur papan beton ringan berserat sabut kelapa dengan (a) sikacim concrete additive (b) katalis MEKPO

Kuat lentur yang dihasilkan pada pengujian dan perhitungan melalui Persamaan (4) sesuai Gambar 4 (b) semakin menurun ketika penambahan aluminium pasta yang diberikan semakin meningkat kecuali pada penambahan aluminium pasta $0,1 \%$. Meningkatnya nilai kuat lentur papan beton ringan sebanding dengan penambahan umur papan beton. Hal ini terjadi pada masing-masing penambahan aluminium pasta mulai dari $0,05 \%$ hingga $0,4 \%$. Penambahan aluminium pasta $0,1 \%$ dengan umur 28 hari sebesar $67,5 \mathrm{~kg} / \mathrm{cm}^{2}$ merupakan kuat lentur 
maksimum yang didapatkan. Kuat lentur minimum yang didapatkan telihat pada penambahan aluminium pasta $0,4 \%$ dengan umur 7 hari yaitu sebesar $27 \mathrm{~kg} / \mathrm{cm}^{2}$.

Hasil kuat lentur yang terlihat pada Gambar 4 belum memenuhi standar. Kuat lentur yang dihasilkan masih jauh dibawah standar GRCA (Glassfiber Reinforced Concrete Association) yaitu sekitar 203,947-305,915 kg/cm². Kecilnya nilai kuat lentur yang dihasilkan disebabkan karena ikatan antarmuka (interface) antara serat dengan matriks lemah dan jumlah interface yang terbentuk juga banyak. Lemahnya ikatan interface akan mempengaruhi kekuatan papan beton ringan dalam menahan beban yang diberikan.

\section{KESIMPULAN}

Penambahan aluminium pasta dengan bahan tambahan sikacim concrete additive atau katalis MEKPO pada papan beton ringan berserat sabut kelapa menghasilkan nilai densitas dan porositas sesuai dengan standar SNI 03-2105-2006. Kuat tekan yang dihasilkan sesuai dengan standar SNI 03-3449-2002 sedangkan kuat lentur belum memenuhi.Nilai densitas terendah dihasilkan pada penambahan aluminium pasta $0,4 \%$ sebesar $1,71 \mathrm{~g} / \mathrm{cm} 3$ untuk sikacim concrete additivedan $1,76 \mathrm{~g} / \mathrm{cm} 3$ untuk katalis MEKPO. Penambahan aluminium pasta $0,05 \%$ menghasilkan porositas paling sedikit untuk sikacim concrete additive dan katalis MEKPO secara berurut yaitu sebesar $20,55 \%$ dan $25,65 \%$.Kuat tekan maksimum yang didapat pada penambahan aluminium pasta $0,05 \%$ umur 28 hari dengan tambahan sikacim concrete additive sebesar $78 \mathrm{~kg} / \mathrm{cm} 2$. Kuat tekan maksimum papan beton ringan yang didapatkan termasuk jenis struktural ringan.

\section{DAFTAR PUSTAKA}

Badan Standarisasi Nasional (BSN), SNI 03-3449-2002, Tata Cara Rencana Pembuatan Campuran Beton Ringan Dengan Agregat Ringan, Indonesia, 2002

Badan Standar Nasional (BSN), SNI 03-2105-2006, Papan Serat dan Papan Partikel, Jakarta, 2006

Bledzki, A.K. danGassan, J., Composite Reinforced With Cellulose Based Fibers Progress in Polymer Science McGraw-Hill, New York, 1999

Dzikri, M., Pengaruh Penambahan Superplasticizer pada Beton dengan Limbah Tembaga (Copper Slag) terhadap Kuat Tekan Beton sesuai Umurnya, Jurnal Teknik Sipil Universitas Negeri Surabaya,2,2018

Fibre Technologies International, GRC Guide, fibretech.org/grc-guide/, 2013, diakses(20 Agustus 2018)

Jatmika, L.P, Pengaruh Persentase Serat Sabut Kelapa dan Resin Polyester terhadap Sifat Fisik dan Mekanik Papan Beton Ringan, Jurnal Fisika Unand, 6, hal 387-393, 2018

Putra A W, PengaruhAlumunium Pasta pada Kapasitas Tarik, Tekan, danLentur Bata Ringan dengan Menggunakan Material Lokal, Tesis, Universitas Muhammadiyah Surakarta, 2015

Zulkifly, Nini HA, Romy T, Pengaruh Penambahan Serat Sabut Kelapa Terhadap Kuat Tekan Beton Pada Beton Normal, Jurnal Stabilitas,1, hal 121-128, 2013 